\title{
The Progressive Muscle Relaxation and Try Out of National Exam to the Level of Anxiety
}

\author{
Jajuli Heri Fauzi*, Eka Nugraha, Yusuf Hidayat \\ Universitas Pendidikan Indonesia \\ Bandung, Indonesia \\ *jajuliishere@rocketmail.com
}

\begin{abstract}
The purpose of the study was to investigate the effect of progressive muscle relaxation and try out of national exam on decreasing anxiety levels in the face of national examination. The method used is quasi experimental method. The population of high school students of class XII boarding school and public school in Sukabumi city with the sample of each group of 31 students from Hayatan Thayyibah and SMAN 2 High School by using saturated sampling and purposive sampling technique. Instruments adopted LWASQ relate to modified anxiety indicators. The results of the study showed significant effect of PMR and TO training on the anxiety level of boarding schools as well as public schools, and PMR can be presented as an alternative to reduce anxiety and will be more effectively applied to boarding students.
\end{abstract}

Keywords-PMR; TO; boarding school; national exam; anxiety

\section{INTRODUCTION}

Anxiety is one of the important things that normally and regularly occur emotions [1]. Experts agree to say that this negative impact anxiety is something that can arise whenever it happens to someone, it is necessary to intervene in cases of anxiety disorder [2], therefore anxiety needs appropriate action. Psychological symptoms that affect each individual are difficult to predict, anxiety or depression disorders are based on a diagnosis of feelings [3]. Basic emotional expressions such as anxiety or fear may come from each individual biologically [4]. Anxiety is an emotional state that arises and can be defined as an affective or emotional basic feeling, perceptive or psychomotor, and cognitive components [1].

The argument of teenage perception (students) and family conflict is a small part of various teen anxieties such as depression and physical symptoms [5]. Therefore, class XII students of boarding schools and public schools in the city of Sukabumi who will face national examinations must have the ability to reduce anxiety symptoms. Unable to control anxiety symptoms, it is feared that students will experience symptoms of stress just before testing that have a detrimental effect on memory [6], so it is necessary to control the students when facing national exams do not experience high levels of anxiety. Stress management studies were identified, calculated and classified in the following categories: arousal reduction approaches namely, image / relaxation / meditation biofeedback, coping training skills namely, multicomponent cognitive behavior [7]. In conducting stress management there are several ways that can be used to manage stress, because in other studies found an increase in memory performance in individuals who are stressed before learning [8,9].

PMR is a relaxation technique that trains an individual to identify tension in various ways, the muscle group is stretched and then relaxes at once [10]. PMR includes intentional stretching and relaxation of the main body muscle groups starting with the hands and ending in the legs [11]. The literature explains the study of the ways in which PMR improves the quality of life [12]. In another study the benefits of PMR training had a direct effect, reducing pulse rate 2.35 beats / minute, systolic blood pressure $5.44 \mathrm{~mm} \mathrm{Hg}$, and diastolic blood pressure $3.48 \mathrm{~mm} \mathrm{Hg}$, then after 4 weeks of PMR training, further decline in the pulse to 2.9 beats / minute, systolic blood pressure becomes $5.1 \mathrm{~mm} \mathrm{Hg}$, and diastolic blood pressure to $3.1 \mathrm{~mm} \mathrm{Hg}$ occurs [13]. One of these nonpharmacological methods, namely progressive muscle relaxation is a therapeutic method that is widely used to induce nerve muscle relaxation [14]. It has been shown to be associated with findings that indicate that PMR is effective in overcoming fatigue [15], pain relief, decreased levels of depression and anxiety [16] and improved sleep quality [17]. The implementation of PMR training consists of successively tense and relax at least five major muscle groups, starting with the upper body and proceeding to the bottom [18].

According to Bartlet and Vavrus that the national curriculum has strengthened teacher-centered teaching methods to prepare students for national exams [19], the results can be used by students to find out what material has been mastered and which have not been mastered. From these results students are expected to be able to catch up with material that has not been mastered. Research has investigated the determinants of participation in additional learning activities such as TO, the results have an effect on students' academic performance [20]. When students can prepare TO exam several study sessions, they tend to coordinate self-testing and learn TO until they correctly remember each concept at least once [21]. Historically the tests were designed and assessed by school teachers, but centralized exams (national exams) at the end of school play an important role in many education systems throughout the world. The desired centralized evaluation because they improve student achievement will influence the incentive structure of stakeholders in the education system [22]. 
In terms of emotional states, individuals can express feelings of fear, insecurity, apprehensive anticipation, and increased standby time [23]. Recent studies include analyzing personality characteristics in relation to stress, Mental in an individual will be different according to the adjustment and mindset of the individual, symptoms of stress will arise if the individual is unable to control his situation [24]. The level of anxiety experienced and felt by students before the national exam, will be one of the determinants of student graduation from school [25]. The emergence of anxiety when facing an exam, the possibility of students' thinking ability at that time stopped functioning effectively [26]. The hope that students are accustomed and trained with national exam questions, the more they practice, of course students are expected to be more ready to face national exams, also by adding a guide will have an impact on 'full-time schooling', such as explaining patterns and processes in the school system and on the tutoring itself [27]. Anxiety test is needed to motivate and help students mentally remain physically alert, because a little anxiety tends to stimulate someone to perform better [28].

Studies show that the PMR group experienced a much better increase in anxiety, depression, and quality of life scores than the control group after PMR training [29]. The results of the study [30], have a significant correlation between the results of cognitive tests TO and national examination subjects for students of class XII of SMA Negeri Banda Aceh in $2014 / 2015$ academic year. Relaxation therapy is an effective and useful psychological intervention in addition to anxiety symptoms, the current study provides evidence that the use of relaxation therapy can reduce symptoms of depression, phobia, and worry in people who experience anxiety disorders [31]. The author formulates a hypothesis that there is a significant effect of PMR and TO training on anxiety levels, and there are differences in the effect of PMR and TO high school students in class XII of boarding schools and public schools facing national exams in the city of Sukabumi. The purpose of this study was to examine the differences in influence between boarding schools and public schools.

\section{METHODS}

\section{A. Participants}

The target population of high school students in the class XII boarding school and general school in the city of Sukabumi, as well as an affordable population of Hayatan Thayyibah Integrated High School dormitory schools as many as 31 students and public schools of SMAN 2 Kota Sukabumi as many as 327 students.

Research uses saturated sampling for samples of boarding schools, "... generalizable sample sizes cannot be determined given the need for a thorough exploration ..." [32], that a generalized sample size cannot be determined in advance for exploration needs thorough. As well as purposive sampling for public school samples, which is a process in which the subject is chosen by the investigator to fulfill certain objectives [33].

\section{B. Procedurs}

TABLE I. INSTRUCTIONS FOR PMR TRAINING [34].

\begin{tabular}{|c|c|}
\hline Muscle Group & Instructions \\
\hline Hand & $\begin{array}{l}\text { Clench your left hand and feel the tension } \\
\text { Relax and let hand hang loosely. Same for } \\
\text { right hand. }\end{array}$ \\
\hline Wrists & $\begin{array}{l}\text { Bend hand back, hyperextending your } \\
\text { wrists. Relax. }\end{array}$ \\
\hline Upper arms & $\begin{array}{l}\text { Bend elbow towards your shoulders and } \\
\text { tense biceps muscle. Relax. }\end{array}$ \\
\hline Shoulders & $\begin{array}{l}\text { Bring shoulders up toward yours ears. } \\
\text { Relax, let your shoulders drop down. }\end{array}$ \\
\hline Forehead & $\begin{array}{l}\text { Wrinkle your forehead, raise your } \\
\text { eyebrows. Relax. }\end{array}$ \\
\hline Eyes & Close your eyes tightly. Relax. \\
\hline Jaws & Clench your jaws tightly. Relax. \\
\hline Tongue & $\begin{array}{l}\text { Press your tongue against the roof of your } \\
\text { mouth. Relax. }\end{array}$ \\
\hline Mouth & Press your lips together tightly. Relax. \\
\hline Neck & $\begin{array}{l}\text { Turn your head so that your chin is over } \\
\text { your right shoulder. Straighten and relax. }\end{array}$ \\
\hline Neck and Jaws & $\begin{array}{l}\text { Bend your head forward, pressing your } \\
\text { chin against your chest. Straighten and } \\
\text { relax. }\end{array}$ \\
\hline Chest & $\begin{array}{l}\text { Take a deep breath and hold it for } 5 \\
\text { seconds, slowly exhale and relax. }\end{array}$ \\
\hline Abdomen & Tighten your stomach muscles. Relax. \\
\hline Back & Arch your back. Relax. \\
\hline Thighs & $\begin{array}{l}\text { Stretch your legs in front of you. Tighten } \\
\text { your thigh muscles. Relax. }\end{array}$ \\
\hline Hamstrings & $\begin{array}{l}\text { Push your heels down into floor, tighten } \\
\text { your hamstring muscles. Relax. }\end{array}$ \\
\hline Calves & Point your toes toward your head. Relax. \\
\hline Feet & $\begin{array}{l}\text { Curl your toes toward the bottom of your } \\
\text { feet. Relax. }\end{array}$ \\
\hline
\end{tabular}

Measurements were carried out before and after the sample was treated with PMR. According to the statement that "measurements were done before the treatment session and after 1st week, 2nd week, 3rd week and 4th week" [35]. When implementing PMR training, "... for 15 minutes per day, 3 days per week ..." [36], which is for 15 minutes per day, 3 days per week conducted by the researcher. Supported by other sources regarding the PMR training time, "The programs were performed over a 4-week period ..." [37], that the program was carried out over a 4-week period.

\section{Instruments}

This study the authors adopted instruments covering somatic, behavioral and cognitive aspects related to anxiety indicators [38], to measure the anxiety level of class XII students using a scale.

The statement item was a modification of the Lehrer Woolfolk Anxiety Symptom Questionnaire (LWASQ) which was arranged with a reliability value of 0.91 for the behavioral sub-component, for the cognitive sub-component 0.92 and for the somatic sub-component 0.93 [39]. Each statement item has a scale score range of 0 to 8 .

Selection of items by testing the validity and reliability of anxiety scale through the Statistical Product and Service 
Solution (SPSS) application program using corrected item total correlation and with Cronbach's Alpha.

\section{RESULTS AND DISCUSSION}

TABLE II. HYPOTHESIS I TEST

\begin{tabular}{|c|c|c|c|c|c|c|c|c|}
\hline \multicolumn{9}{|c|}{ Paired Samples Test } \\
\hline & \multicolumn{5}{|c|}{ Paired Differences } & \multirow[t]{3}{*}{$t$} & \multirow[t]{3}{*}{$d f$} & \multirow{3}{*}{\begin{tabular}{|c|} 
Sig. \\
$(2-$ \\
tailed $)$
\end{tabular}} \\
\hline & \multirow[t]{2}{*}{ Mean } & \multirow[t]{2}{*}{$\begin{array}{c}\text { Std. } \\
\text { Deviation }\end{array}$} & \multirow[t]{2}{*}{$\begin{array}{l}\text { Std. } \\
\text { Error } \\
\text { Mean }\end{array}$} & \multicolumn{2}{|c|}{$\begin{array}{l}95 \% \text { Confidence } \\
\text { Interval of the } \\
\text { Difference }\end{array}$} & & & \\
\hline & & & & Lower & Upper & & & \\
\hline \begin{tabular}{|l|l|} 
Pair 1 & pretest \\
postest
\end{tabular} & 23,2 & 15,2 & 2,7 & 17,6 & 28,8 & 8,4 & 3 &, 000 \\
\hline
\end{tabular}

The table 2 above shows the results of the SPSS 20 test through a paired samples $t$ test technique to the anxiety level of the boarding school group having a sig value. (2-tailed) smaller than the value of $\alpha=0.05$, which is 0,000 . This means that there is a significant effect of PMR and TO training on the level of anxiety of high school students in class XII of boarding schools facing national examinations in the city of Sukabumi, after treatment.

TABLE III. HYPOTHESIS II TEST

\begin{tabular}{|c|c|c|c|c|c|c|c|c|}
\hline \multicolumn{9}{|c|}{ Paired Samples Test } \\
\hline & \multicolumn{5}{|c|}{ Paired Differences } & \multirow{3}{*}{$\vec{e} t$} & \multirow[t]{3}{*}{$d f$} & \multirow{3}{*}{\begin{tabular}{|c|} 
Sig. \\
$(2-$ \\
tailed \\
)
\end{tabular}} \\
\hline & \multirow[t]{2}{*}{ Mean } & \multirow[t]{2}{*}{$\begin{array}{c}\text { Std. } \\
\text { Deviation }\end{array}$} & \multirow[t]{2}{*}{$\begin{array}{c}\text { Std. Error } \\
\text { Mean }\end{array}$} & \multicolumn{2}{|c|}{\begin{tabular}{|c|}
$95 \%$ Confidence \\
Interval of the \\
Difference
\end{tabular}} & & & \\
\hline & & & & Lower & Upper & & & \\
\hline Pair $1 \begin{array}{l}\text { pretest } \\
\text { postest }\end{array}$ & 16,0 & 11,5 & 2,0 & 11,8 & 20,3 & 7,7 & 3 &, 000 \\
\hline
\end{tabular}

The table 3 above shows the results of the SPSS 20 test through a paired samples $t$ test technique to the anxiety level of a public school group having a sig value. (2-tailed) smaller than the value of $\alpha=0.05$, which is 0,000 . This means that there is a significant effect of PMR and TO exercises on the level of anxiety of high school students in class XII of public schools facing national exams in the city of Sukabumi, after the treatment.

TABLE IV. HYPOTHESIS III TEST

\begin{tabular}{|c|c|c|c|c|c|c|}
\hline \multicolumn{7}{|c|}{ Independent Samples Test } \\
\hline & & \multicolumn{2}{|c|}{$\begin{array}{c}\text { Levene's Test for } \\
\text { Equality of } \\
\text { Variances }\end{array}$} & \multicolumn{3}{|c|}{$\begin{array}{c}\text { t-test for Equality of } \\
\text { Means }\end{array}$} \\
\hline & & $F$ & Sig. & $t$ & $d f$ & \begin{tabular}{|c|} 
Sig. \\
$(2-$ \\
tailed $)$
\end{tabular} \\
\hline Gain & $\begin{array}{c}\text { Equal variances } \\
\text { assumed }\end{array}$ & 2,43 &, 12 & 2,08 & 60 &, 042 \\
\hline & $\begin{array}{c}\text { Equal variances } \\
\text { not assumed }\end{array}$ & & & 2,08 & 55,88 &, 042 \\
\hline
\end{tabular}

Based on the results of the SPSS output, the sig value is obtained. (2-tailed) of 0.042 . Because the p-value is smaller than the value of $\alpha=0.05(0.042<0.05)$. This means that there are differences in the effect of PMR and TO training on the anxiety level of XII grade high school students in boarding schools and public schools facing national exams in the city of Sukabumi.

There are 2 factors that influence student learning outcomes, namely internal factors and external factors [40], internal factors are factors that arise from within, while external factors are factors that come from outside. External factors include family, school, community and neighborhood. Obviously giving an explanation that the place of residence of students as one of the external factors has an influence on the results. Dormitory as a place of residence is one of the external factors that influence student learning outcomes, as well as students who live in dormitories are higher in learning outcomes compared to students who live in parents' homes [41]. This shows that the dormitory as a place of residence that supports learning outcomes is good for students. The relationship between residence and learning outcomes is interrelated with each other. Regarding the place of residence of students on learning outcomes concluded that the residence of students can improve maximum quality results, especially in student learning outcomes [42].

This can happen when viewed from the characteristics of students who have different public schools, adaptation of the environment in which the process of learning activities and daily activities inside and outside the school are different when compared to boarding school students. Each student has their own unique way of learning, students vary when deciding what, how long and how to learn [43]. Then the developmental factors can affect the age of adolescence according to Nurihsan and Agustin [44]. The role of parents in giving direction and education to students in general schools determines the formation of students' character in physical and psychological, social, and spiritual aspects of growth and development. Home as a place for students to live with their parents gives students the possibility to get education from parents so they can socialize with the environment around the house [45].

"Learning outcomes focus on what students have achieved rather than marvelously focused on the content of what has been taught and focus on what students can demonstrate at the end of a learning activity" [46], that there are emphasis on students can demonstrate at the end of learning activities, if the student can demonstrate well it can be said that learning outcomes have been achieved well. There are differences in the influence of PMR and TO national exams on the level of anxiety in class XII students of high school boarding schools and public schools in Sukabumi City. Previously there were several influential factors, they analyzed the simultaneous impact of demographic aspects, personality, intelligence, and their behavior in learning outcomes [47]. Research shows that relaxation techniques offer alternative ways to learn easily to cope with temporary stress and anxiety, and there is a significant correlation between the cognitive test results of TO and national exam subjects of class XII students of Banda Aceh City Senior High School 2014/2015 academic year [30]. Supporters of this study as well as argued by the results of Davies' research explain that progressive muscle relaxation is a relaxation technique and has been proven to be the most effective way to reduce stress and anxiety [48]. 


\section{CONCLUSIONS}

The results of the study showed that there was a significant effect of PMR and TO training on the level of anxiety of boarding schools and public schools, and there were differences in the effect of PMR and TO training on the level of anxiety of boarding schools and public schools facing national exams in Sukabumi. Seeing from a theoretical point of view relaxation training (PMR) is continuous which has a significant influence on efforts to overcome psychological problems, as well as determinants of participation in additional learning activities such as TO which affect student academic achievement. The discussion that has been described in detail in the previous chapter, then PMR can be presented as an alternative to reduce anxiety and the results will be more effectively presented to boarding students.

To users of research results or teachers and other educators so that they can apply PMR as a solution to overcome anxiety before the national exam, because by giving relaxation exercises carried out continuously can have a significant influence on efforts to overcome psychological problems of students. The application of sports physical activity groups in the exercise program as a comparison of the level of anxiety between boarding schools and public schools needs to be applied for further research. There is a limitation of research by using a scale that is sometimes the answers given by the sample do not show the real situation, it is necessary to check the pulse state to find out more symptoms.

\section{REFERENCES}

[1] K. Wiedemann, "Anxiety and Anxiety Disorders. International Encyclopedia of the Social \& Behavioral Sciences: Second Edition (Second Edition, Vol. 1)," Elsevier, 2015.

[2] B.S. McEwen, L. Eiland, R. G. Hunter and M.M. Miller, "Stress and anxiety: Structural plasticity and epigenetic regulation as a consequence of stress," Neuropharmacology, vol. 62, no. 1, pp. 3-12, 2012.

[3] A. Damasio and G. B. Carvalho, "The nature of feelings: Evolutionary and neurobiological origins," Nature Reviews Neuroscience, vol. 14, no. 2, pp. 143-152, 2013.

[4] R. E. Jack, O.G. B. Garrod, H. Yu, R. Caldara and P. G. Schyns, Facial expressions of emotion are not culturally universal, pp. 4-7, 2012.

[5] S. Hansell, "Divorce, Family Conflict, and Adolescents 'Well-Being *," vol. 30, no. 1, pp. 105-116, 2014.

[6] S. Kuhlmann, M. Piel and O. T. Wolf, "Impaired Memory Retrieval after Psychosocial Stress in Healthy Young Men," vol. 25, no. 11, pp. 2977-2982, 2005

[7] L. Ong, W. Linden, and S. Young, "Stress management: What is it?," Journal of Psychosomatic Research, vol. 56, no. 1, pp. 133-137, 2004.

[8] U. M. Nater, C. Moor, U. Okere, R. Stallkamp, M. Martin, U. Ehlert and M. Kliegel, "Performance on a declarative memory task is better in high than low cortisol responders to psychosocial stress. Psychoneuroendocrinology," vol. 32, no. 6, pp. 758-763, 2007

[9] T. Smeets, T. Giesbrecht, M. Jelicic and H. Merckelbach, "Contextdependent enhancement of declarative memory performance following acute psychosocial stress," Biological Psychology, vol. 76, no. 1-2, pp. 116-123, 2007

[10] D. Vancampfort, C.U. Correll, T. W. Scheewe, M. Probst, A. De Herdt, J. Knapen and M. De Hert, Progressive muscle relaxation in persons with schizophrenia: A systematic review of randomized controlled trials. Clinical Rehabilitation, vol. 27, no. 4, pp. 291-298, 2013

[11] A. Muller and H. Hammill, "The Effect of Pilates And Progressive Muscle Relaxation Therapy (Mrt) on Stress and Anxiety During
Pregnancy: a Literature Review," South African Journal of Sports Medicine, vol. 27, no. 6, pp. 53, 2015.

[12] L. Zhao, H. Wu, X. Zhou, Q. Wang, W. Zhu, and J. Chen, "Effects of progressive muscular relaxation training on anxiety, depression and quality of life of endometriosis patients under gonadotrophin-releasing hormone agonist therapy," European Journal of Obstetrics Gynecology and Reproductive Biology, vol. 162, no. 2, pp. 211-215, 2012.

[13] S. Sheu, I. B. L. Irvin, I. H. L. I. C. Mar, H. Lin and C. Mar, Effects of Progressive Muscle Relaxation on Blood Pressure and Psychosocial Status for Clients with Essential Hypertension in Taiwan, pp. 14-19, 2003.

[14] I. Gökşin and S. Ayaz-Alkaya, "The Effectiveness of Progressive Muscle Relaxation on the Postpartum Quality of Life," Asian Nursing Research, pp. g1-5, 2018

[15] M. Guszkowska, K. Sempolska, A. Zaremba and M. Langwald, "Exercise or relaxation? Which is more effective in improving the emotional state of pregnant women?" Human Movement, vol. 14, no. 2, pp. 168-174, 2013.

[16] M. L. C. Bsn and M. O. Malley, Progressive muscle relaxation to decrease anxiety in clinical simulations. Teaching and Learning in Nursing, vol. 10, no. 2, pp. 57-62, 2015.

[17] L. Vadas, Z. Arnon, N. Ziv, I. Kremer and I. Haimov, "al us e on om m er on on $\mathrm{m}$ er al, 4, 2012.

[18] A. Georgiev, M. Probst, M. Hert, De, and D. Vancampfort, "Subjective well-being in chronic Bulgarian patients with Schizophrenia," ACUTE EFFECTS OF PROGRESSIVE MUSCLE RELAXATION ON STATE ANXIETY AND SUBJECTIVE WELL-BEING EFFECTS IN, (May 2014), 2012.

[19] D. M. Roberts, "Cracks in support for two Tanzanian rural primary schools with high performance on national exams," International Journal of Educational Development, vol. 43, pp. 32-40, 2015

[20] A. Tansel and F. Bircan, "Demand for education in Turkey: A tobit analysis of private tutoring expenditures," Economics of Education Review, vol. 25, no. 3, pp. 303-313, 2006

[21] J. L. Janes, J. Dunlosky and K. A. Rawson, "How Do Students Use SelfTesting Across Multiple Study Sessions When Preparing for a HighStakes Exam?" Journal of Applied Research in Memory and Cognition, 2018.

[22] G. Schwerdt and L. Woessmann, "The information value of central school exams," Economics of Education Review, vol. 56, pp. 65-79, 2017.

[23] P. Muris, E. Simon, H. Lijphart, A. Bos, W. Hale and I. I. I. Kelly, "The Youth Anxiety Measure for DSM-5 ( YAM-5 ): Development and First Psychometric Evidence of a New Scale for Assessing Anxiety Disorders Symptoms of Children and Adolescents," vol. 5, 2016.

[24] I. Peciuliene, A. Perminas, L. Gustainiene and G. Jarasiunaite, "Effectiveness of Progressive Muscle Relaxation and Biofeedback Relaxation in Lowering Physiological Arousal among Students with Regard to Personality Features," Procedia - Social and Behavioral Sciences, 205(May), pp. 228-235, 2015.

[25] H. Qudsyi and M. I. Putri, "Self-efficacy and Anxiety of National Examination among High School Students," Procedia - Social and Behavioral Sciences, vol. 217, pp. 268-275, 2016.

[26] P. Vitasari, M. N. A. Wahab, T. Herawan, A. Othman and S. K. Sinnadurai, "Validating the instrument of study anxiety sources using factor analysis," Procedia - Social and Behavioral Sciences, 15, 38313836, 2011 .

[27] M. Bray and P. Kwok, "Demand for private supplementary tutoring: Conceptual considerations, and socio-economic patterns in Hong Kong," Economics of Education Review, vol. 22, no. 6, pp. 611-620, 2003.

[28] P. Birjandi and M. Alemi, "The Impact of Test Anxiety on Test Performance among Iranian EFL Learners. BRAIN," Broad Research in Artificial Intelligence and Neuroscience Autumn, vol. 1, no. 4, pp. 4458,2010

[29] L. Pan, J. Zhang and L. Li, "Effects of progressive muscle relaxation training on anxiety and quality of life of inpatients with ectopic pregnancy receiving methotrexate treatment," Research in Nursing and Health, vol. 35, no. 4, pp. 376-382, 2012. 
[30] Y. Elfiza, Rusman and M. Nasir, "Hubungan antara Hasil Uji Kognitif Try Out Ujian Nasional ( UN ) dengan Hasil Ujian Nasional ( UN ) Mata Pelajaran Kimia SMA Kota Banda Aceh Tahun Ajaran 2014 2015," Ilmiah Mahasiswa Pendidikan Kimia, vol. 1, no. 3, 35-42, 2006.

[31] H.s Kim and E. J. Kim, "Effects of Relaxation Therapy on Anxiety Disorders: A Systematic Review and Meta-analysis," Archives of Psychiatric Nursing, vol. 32, no. 2, pp. 278-284, 2018.

[32] R. T. Trotter, "Qualitative research sample design and sample size: Resolving and unresolved issues and inferential imperatives," Preventive Medicine, vol. 55, no. 5, pp. 398-400, 2012.

[33] E. A. Panacek and C. B. Thompson, "Sampling methods: Selecting your subjects,” Air Medical Journal, vol. 26, no. 2, pp. 75-78, 2007.

[34] A. Khanna, M. Paul and J. S. Sandhu, "Efficacy of two relaxation techniques in reducing pulse rate among highly stressed females", vol. 5, no. 2, pp. 6-8, 2007.

[35] Deepti Dhyani, Dr Siddhartha Sen, D. R. R., "Effect of stabilization exercise on pain and disability in patients with chronic low back pain," Indian J Physiotherapy and Occupational Ther, vol. 9, no. 2, pp. 170 $175,2015$.

[36] P. K. Chatt, "Effect of o Muscle e Relaxati ion Train ning as a Function of Im mprovem ment in Att tentivene ess in Chil ldren," 91, 606-613, 2013.

[37] J. W. Suh, S.Y. Chung, S. Y. Kim, J. H. Lee and J. W. Kim, “Anxiety and Anger Symptoms in Hwabyung Patients Improved More following 4 Weeks of the Emotional Freedom Technique Program Compared to the Progressive Muscle Relaxation Program: A Randomized Controlled Trial," Evidence-Based Complementary and Alternative Medicine, 2015.

[38] P. M. Lehrer and R. L. Woolfolk, "Self-report assesment of anxiety: Somatic, cognitive, and behavioral modalities," Behavioral Assessment, vol. 4, pp. 167-177, 1982.
[39] A. Scholing and P. M. G. Emmelkamp, "Self report assessment of anxiety: A cross validaiton of the Lehrer Woolfolk Anxiety symptom questionnaire in three populations, vol. 30, no. 3, 1992.

[40] M. Dalyono, Psikologi Pendidikan. Jakarta. Rineka Cipta, 2009.

[41] M. K. Ningtias, "SISTEM BOARDING SCHOOL DI SMA MUHAMMADIYAH 1 GRESIK Mai Kurniasari Ningtias,” E-Journal Unesa, vol. 1, pp. 2-7, 2013.

[42] R. Indriyani, "Pengaruh Asal Sekolah Dan Tempat Tinggal Terhadap Prestasi Belajar Mahasiswa Prodi DIII Kebidanan Universitas Wiraja Sumenep," Universitas Sebelas Maret Surakarta, pp. 34-39, 2014.

[43] E. K. Chang and P. F. Wimmers, "Effect of Repeated/Spaced Formative Assessments on Medical School Final Exam Performance," Health Professions Education, vol. 3, no. 1, pp. 32-37, 2017.

[44] A. Nurihsan and M. Agustin, Dinamika Perkembangan Anak \& Remaja, Tinjauan Psikologi, Pendidikan, dan Bimbingan, Bandung: Refika Aditama, 2013.

[45] H. Frick, and H. M. Tri, Arsitektur Ekologis. Yogyakarta. Penerbit Kanisius, 2006.

[46] D. Kennedy, A. Hyland and N. Ryan, "Writing and using learning outcomes: a practical guide. Bologna Handbook - Making Bologna Work, (January 2007), 2006

[47] B. B. de Koning, S. M. M Loyens, R. M. J. P. Rikers, G. Smeets and H T. van der Molen, "Generation Psy: Student characteristics and academic achievement in a three-year problem-based learning bachelor program," Learning and Individual Differences, vol. 22, no. 3, pp. 313 323, 2012.

[48] Komarudin, Psikologi Olahraga. Bandung: PT. Remaja Rosdakarya, 2016 